ISSN: 2581-8341

Volume 04 Issue 01 January 2021

DOI: 10.47191/ijcsrr/V4-i1-01, Impact Factor: 6.595

IJCSRR@ 2021

www.ijcsrr.org

\title{
Sex in Stencil Novels Case Study: Readers' Reception of Enny Arrow's Stencil Novel in Surakarta
}

\author{
Ariska Puspita Anggraini ${ }^{1}$, Dwi Susanto ${ }^{2}$, Wakit Abdullah ${ }^{3}$ \\ ${ }^{1}$ Student of Cultural Studies, Postgraduate program, UNS, Surakarta, Indonesia \\ ${ }^{2}$ Lecturer of Cultural Studies, UNS, Surakarta, Indonesia \\ ${ }^{3}$ Lecturer of Cultural Studies, UNS, Surakarta, Indonesia
}

\begin{abstract}
The phenomenon of sex has always been novel in every era. In Indonesia, for example, Enny Arrow's stencil novel has been circulating, which has been named as a legend of Indonesian erotic literature. Along with the development of technology, the existence of stencil novels was replaced by DVDs or VCDs, which then continued with the emergence of various sites providing access to pornography. This difference in phenomena certainly makes the meaning of sex for each individual different. This research will analyze the meaning of sex in the stencil novel by Enny Arrow in the eyes of millennial men. The data analysis will focus on social psychological factors using Normand Holland's literary reception theory. From the data analysis, it can be concluded that there are different views on sexual relations before and after reading the novel. This research is expected to provide a new perspective on the picture of sexuality for modern humans.
\end{abstract}

KEYWORDS: Sex, Stencil novels, Pornography, millennial, modern, Normand Holland

\section{INTRODUCTION}

Talking about sex always has the power of sensational for anyone at any time. Every era always presents a different sex phenomenon. In Indonesia, for example, from the 1970s to the end of the 1990s, Enny Arrow's stencil novels were circulating. As technology developed, the existence of Enny Arrow's stencils sank and was replaced by DVDs or VCDs, which continued with the emergence of various pornographic content provider platforms.

The difference in this phenomenon certainly makes the meaning of sex for each individual different. The experience of reading a stenciled novel provides a different experience than the experience of accessing pornographic content on the internet, which is mostly packaged in video form. This will also provide a different understanding of the way millennials interpret the meaning of sex.

Pornography, as a representation of sexuality, can distort individual concepts of relations with the opposite sex. In this regard, this study will analyze the picture of sexuality in Enny Arrow's stencil novel according to the views of millennial men, especially regarding the individual concept of relationships with the opposite sex. This study used a material object in the form of a stencil novel by Enny Arrow with a randomly selected title.

Enny Arrow's stencil novel was deliberately chosen as the material object because this erotic literature still has a lot of interest. Pornography and eroticism have a high appeal because they create both fear and curiosity (Prabasmoro, 2007: 291). Even though stencil novels are no longer successful in the modern era, the public's enthusiasm for Enny Arrow's stencils is fairly high. Some millennials who are not familiar with these stencils are even interested in experiencing the experience of reading the novel by Enny Arrow.

This study uses Normand Holland's theory of reader-response criticism. Holland's theory of ideas uses a psychoanalytic approach to determine the reactions and responses of readers in interpreting a work. According to Holland (in Tyson, 2006: 182), humans react to literary texts they read in the same psychological way that is carried in everyday life. Since its inception, Enny Arrow's stencil novel has been categorized as a work of erotic literature. Literary work will have no meaning if it does not get a response from its readers. According to Holland (in Tyson, 2006: 182), humans react to literary texts they read in the same psychological way that is carried in everyday life.

The result of interpreting a text is a product of the fear, defense, need, and desire projected by the reader towards the text (Holland in Tyson: 2006: 183). In other words, the reader's interpretation of work reflects themselves, not the text they read. Holland argues that the reader's interpretation of a text is also influenced by gender, age, class, or the reader's experience (1980: 123). Readers who have the same age, gender, class, and interpretation ability will also have similar interpretation results in interpreting a work. 


\section{International Journal of Current Science Research and Review}

ISSN: 2581-8341

Volume 04 Issue 01 January 2021

DOI: 10.47191/ijcsrr/V4-i1-01, Impact Factor: 6.595

IJCSRR@ 2021

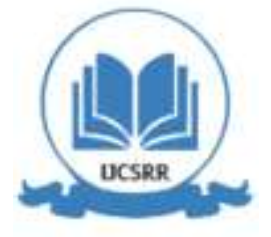

www.ijcsrr.org

Based on this explanation, this study will analyze social psychological factors, especially those that focus on the reader's ability to interact with the opposite sex, in interpreting a stylized novel by Enny Arrow. The subjects in the study were two millennial men who work in the media industry in Surakarta as representations of modern humans. The research process was carried out for approximately six months by involving observation and in-depth interviews. During this process, research subjects were asked to read various titles of Stencil novels by Enny Arrow and tell their experiences while reading. The research process also involves discussion with the subject to obtain a more in-depth analysis..

\section{THEORETICAL EVIDENCE}

\section{Literary Reception}

Literary reception theory is used to see how readers can give meaning to the literary works they read so that they can react or respond to them (Junus, 1984: 1). The process of reading work also involves the real experience of the reader (Holland, 1990: 3). Therefore, the reader's interpretation of the work they read also reflects the reality they have.

Readers' interpretation of a text aims to fulfill their psychological needs and desires. When reading, the defense mechanisms that appear in the reader's interpersonal life also arise because the reader's interpretation of work also reflects their psychological condition (Holland in Tyson, 2006: 182-183). Holland also calls interpretation to express the theme of identity so that each reader has a different interpretation (1980). To interpret the work they read, the reader and the text that are read experience an interaction consisting of three stages, namely: defense-fantasy-transformation (DeFT).

Summarizing Holland's work entitled "Unity Identity Text Self (1980), the DeFT stages are as follows:

a. Defense: the text raises a psychological defense in the reader. The text reminds the reader of his life experiences.

b. Fantasy: in this stage, the reader finds a way to interpret the text so that the reader is able to achieve a psychological balance.

c. Transformation: the reader begins to focus on intellectual interpretations to avoid emotional responses in him.

\section{Sex in the eyes of modern humans}

In modern times, access to pornography is increasingly wide open, resulting in the formation of sex as a commodity whose meaning focuses on sexual intercourse and sex (Gunawan, 2000: 3-4). This has resulted in modern humans being considered only as a consumption need. When viewed in this way, sex has the potential to lead to uncontrolled consumption. One concrete evidence has been proven by a study from the Ministry of Communication and Information (Kemenkoninfo), which states that the millennial generation is the most access to pornographic content on the internet (Elshinta, 2019). In fact, there are now many paid platforms that provide pornographic content.

This view of reduced sex can also distort the individual's concept of relations with the opposite sex. For a man, for example, the biggest trigger that makes him attractive to sexual things is the visual image of a woman's body (Van Belkom 55-56: 2001). According to Foucault (in Baker 312-313), since the early eighteenth century, the female body has become the subject and target of modern scientific discourse. This results in women being seen as a source of male pleasure.

\section{METHODOLOGY}

\section{Research Subjects and Locations}

The subjects of this study were two millennial men who work in the media industry. This research is located in Surakarta and was conducted for six months, from December 2019 to May 2020. For privacy purposes, the names of the research subjects will be changed to male A and male B. Men A and B work together as social media specialists in a media company. Online nationwide located in the city of Solo. With this professional background, the two men in this study were considered to have qualified knowledge in accessing technology and the internet.

The two research subjects were the same age and were not married but had different social and psychological backgrounds. Male A was born in 1997. Man, A' s childhood, was spent in Pekanbaru. Male B was born in 1997 and spent his childhood in the city of Solo. This difference certainly influences the way they interpret the stencil novel by Enny Arrow that is read.

\section{Data collection and analysis techniques}

The research data was collected by asking participants to record the impressions they got while reading a stencil novel. Specifically, research subjects were given worksheets to record the impressions they had while reading Enny Arrow's stenciled novels. The data collection instrument is in the form of a spreadsheet or "reader-response worksheet". The worksheet contains instructions that the 


\section{International Journal of Current Science Research and Review}

ISSN: 2581-8341

Volume 04 Issue 01 January 2021

DOI: 10.47191/ijcsrr/V4-i1-01, Impact Factor: 6.595

IJCSRR@ 2021

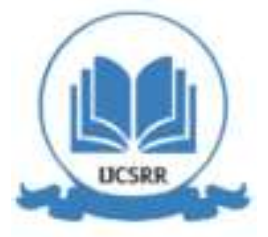

www.ijcsrr.org

research subject should follow when reading Enny Arrow's stencil novel. The following is the contents of the worksheet given to the research subjects:

a. Write down the title of the novel by Enny Arrow that has been read.

b. Write down the lines or scenes in Enny Arrow's most memorable novels.

c. Write down the reasons why you chose the scene or dialogue.

After being asked to fill in the worksheet, observations and in-depth interviews were carried out. Observations were carried out for more than six months to find out daily life and get to know more about the personality of the research subject. Meanwhile, in depth interviews were conducted to obtain more detailed information about the social psychology of the subject in the study.

\section{FINDINGS}

Each of the men in this study was given a handout called a "reader-response worksheet". They were also asked to read stenciled novels entitled "Selembut Sutra", "Sepanas Bara", "Kutak-Kutik Asmara", and "Hari Kelabu". Even though they have different titles, most of the contents of the story in the novel are about the relationship between men and women, which is peppered with sex scenes. Before the reading process, each man was also asked several questions to explore the meaning of sexuality that they understood before reading the stencil novel. The following questions were given before the reading process of Enny Arrow's stencil novel:

a. Have you ever consumed pornographic content?

b. What form of pornographic content do you consume often?

c. What made you interested in consuming this content?

d. What do you think sex means?

The answers of each participant were the same, where men A and B had both accessed pornographic content. Both of them more often consume pornographic content, which is packaged in the form of films or videos. They consider pornographic content packaged in the form of films or videos to attract the imagination more quickly so that sexual desire is easier to channel. Meanwhile, pornographic content that is packaged in the form of stories, including novels, makes them have to think hard to understand the content in it so that their sexual desires are more difficult to channel. Both Man A and Man B claimed to be interested in consuming pornographic content out of curiosity. In addition, they consider the content to be a way to open up intimate conversations with other people.

\section{Man A's Reception}

When reading Enny Arrow's novel entitled Selembut Sutra, man A feels that the most memorable dialogues or scenes are as follows: "Benny really likes pretty girls with hairy armpits. In accordance with Benny's experience, usually, these women have hot temperaments."

The narrative cut depicts a detailed description of a woman's body. According to Man A, the detailed description caused disgust when reading it. When reading the text, Man A' s imagination began to work and form a picture after the text. If analyzed with the DEFT model, it can be interpreted that the imagination or fantasy of man A is contrary to his psychological and social background. Based on the beauty standard of the modern era, the presence of underarm hair in women is considered taboo and disgusting. So when he read the description, man A felt that it was not in accordance with his culture.

When reading a novel entitled "Sepanas Bara", man A felt the most memorable scene was when the female and male main characters had sex with the help of a small child. According to him, the scene felt strange and did not match the real world. According to Normand Holland's DEFT model analysis, this is a form of psychological defense for the reader because the images in the text are not according to the culture they adhere to, which considers sex only for adults. For Male A, sex is usually carried out by adults only without having to involve children.

While reading the novel entitled "Hari Kelabu", the following dialogue scenes made a deep impression on man A:

"Mama has been cheating".

This dialogue is spoken by the female lead named Nita to her husband, Bahri. This dialogue is a form of recognition by Nita to her husband if she has had an affair with another man. When reading a novel entitled "Kutak-Kutik Asmara", the scene that made her impression was when a female character, Raras, asked to date by a man named Boy, chose to have sex with another man. According to him, the scene was very funny and surprising. 


\section{International Journal of Current Science Research and Review}

ISSN: 2581-8341

Volume 04 Issue 01 January 2021

DOI: 10.47191/ijcsrr/V4-i1-01, Impact Factor: 6.595

IJCSRR @ 2021

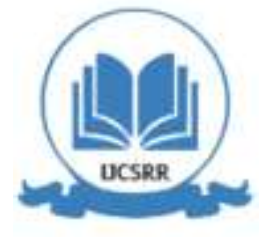

www.ijcsrr.org

Of all the titles, man A felt that the novel entitled "Hari Kelabu" and "Kutak-Kutik Asmara" impressed him the most. When reading a novel entitled "Kutak-Kutik Asmara", Man A felt a connection with a male character named Boy. Pria A also admitted that the dialogue in the novel entitled "Kutak-Kutik Asmara" made him remember the events of his childhood at a glance. If analyzed with Holland's theory, what experienced by man A is a process of "defense" in which the words in the novel create intense emotions. When analyzed with the DEFT model, this is called the "defense" process, where the dialogue or scene creates a psychological defense that makes him remember events in his childhood.

From the overall reading results, man A felt that the scenes in the novel by Enny Arrow that he read did not match the real world. That is why he felt that he could not enjoy the entire contents of the novel he was reading. Man A admitted that he prefers to access sex-related content packaged in videos. For him, accessing pornography through videos is more arousing sexual desire because it is equipped with sound rather than just reading.

\section{Man B's Recepction}

Man B also reads the same novel title as man A. It's just that the scenes or dialogue that impresses man B are mostly in intimate conversations between characters. When reading the novel entitled "Kutak Kutik Asmara", male B felt the memorable scene was when the female and male main characters met. When reading a novel entitled "Sepanas Bara", man B thinks the most memorable scene is when the character Rini asks about the certainty of the male main character Budiman's love for him.

When reading a novel entitled "Hari Kelabu", Pria B felt the most memorable scene was when the character Bahri informed his wife Nita that he had found a formula for his manhood, as if there was hope of happiness. Likewise, when reading a novel entitled "Selembut Sutra", Man B felt that the most memorable scene was when the female and male main characters first met. For male B, all the memorable scenes when reading Enny Arrow's stencil novel show the intimacy between a man and a woman. These scenes are personal so that the relationship between the female and male characters feels more intimate and shows a feeling of love.

If interpreted with the DEFT model, Man B's ego rejects the vulgar scenes in Enny Arrow's novel. For him, sexual relations between men and women do not have to be intimate and do not deserve to be told explicitly. This rejection is a form of defense mechanism from male B thought, such as most Javanese society, which perceives sex as taboo. Male B also thinks that sex also involves feelings so that it cannot be done carelessly, such as the scenes that are told in most of Enny Arrow's novels.

Judging from the way he interpreted sex in Enny Arrow's strategic novel, male B tended to interpret sex in a personal dimension. However, Pria B considers Enny Arrow's stencil novel to be more enjoyable than the pornographic content that is widely circulated on the internet. According to him, the pornographic content that is widely circulating on the internet, especially in the form of videos, is more vulgar and creates a disgusting impression than Enny Arrow's stencil novels. Therefore, he felt that he enjoyed the process of reading Enny Arrow's stencil novel more.

\section{CONCLUSION}

Looking at the reception of men in this study, both of them interpret sex depicted in Enny Arrow's stencil novel as a sexual relationship between a man and a woman. It's just that the focus of man A in interpreting sex lies in consumption to satisfy sexual desire. Therefore, man A could not enjoy the process of reading a stencil novel with Arrow. Male A prefers to enjoy sex-related content in the form of videos because it can arouse sexual desire.

However, man B interpreted sex in Enny Arrow's stencil novel by including a personal element, namely love. For man B, sex is a form of relationship between men and women that must be included in the private sphere. For male B, the sex depicted in Enny Arrow's stencil novel can still be enjoyed because it is not shown clearly. Readers need to understand the writer's words and fantasy will also play more when reading stenciled novels than adult content packaged in videos.

\section{REFERENCES}

1. Baker, Chris. (2005). Cultural Studies: Teori dan Praktik. LonYogyakarta: Bentang Pustaka.

2. Gunawan,FX Rudy, (2000). Refleksi atas Kelamin: Potret seksualitas manusia modern. Magelang: Indonesia Tera.

3. Holland, N. N. (1980). Unity. Identity. Text. Self. In J. Tompkins (Ed.), Readerresponse criticism (pp. 118-134). Baltimore: Johns Hopkins UP.

4. Kusuma, Angga. (2019, December 13). Milenial Pengakses Situs Porno Terbanyak. Retrieved December 20, 2020, from Elshinta website: https://elshinta.com/news/195108/2019/12/13/dekstop 


\section{International Journal of Current Science Research and Review}

ISSN: 2581-8341

Volume 04 Issue 01 January 2021

DOI: 10.47191/ijesrr/V4-i1-01, Impact Factor: 6.595

IJCSRR@ 2021

Www.ijcsrr.org

5. Tyson, Lois. (2008). Critical Theory Today. New York: Routledge.

6. Van Belkom, Edo. (2001). Writing Erotica. Canada: Self-Counsel Press.

Cite this Article: Ariska Puspita Anggraini, Dwi Susanto, Wakit Abdullah (2021). Sex in Stencil Novels Case Study: Readers' Reception of Enny Arrow's Stencil Novel in Surakarta. International Journal of Current Science Research and Review, 4(01), 01-05 